\title{
Assessment of Adequacy of Macro and Micro Mineral Content of Feedstuffs for Dairy Animals in Karnal District of Haryana, India
}

\author{
S. Usha ${ }^{1 *}$ and T.K. Mohanty ${ }^{2}$ \\ ${ }^{1}$ Department of Livestock Production Management, \\ Madras Veterinary College, Chennai, India \\ ${ }^{2}$ ICAR-National Dairy Research Institute, Karnal, Haryana, India \\ *Corresponding author
}

\begin{abstract}
A B S T R A C T
The study was conducted at Cattle Yard of Livestock Farm located at National Dairy Research Institute, Karnal. There are four major seasons in the year viz. rainy, autumn, winter and summer. The fodders and feed fed to Karen fries cattle are collected in all seasons. Four samples of each fodder (green and dry) and concentrates mentioned above were collected in each month (one sample per week) in the respective season. Concentrations of calcium, phosphorus, zinc, copper and manganese were determined. The $\mathrm{Ca}$ level in green fodders was no significant $(\mathrm{P}<0.05)$ difference among the season. Phosphorus level was observed higher in winter $(0.35 \%)$; however, there was significant difference $(\mathrm{P}<0.05)$ among the season. There is no significant difference in other trace minerals $\mathrm{Zn}$. $\mathrm{Cu}$ and $\mathrm{Mn}$ respectively among the season. In dry roughages higher level of calcium was observed in summer season $(0.47 \%)$ and there was no significant difference among the season. Phosphorus level was higher in summer $(0.42 \%)$ lower in rainy $(0.27 \%)$ and significant difference $(\mathrm{P}<0.05)$ in summer and rainy and autumn season. Trace minerals zinc, copper and manganese were no significant difference among the season. In concentrates both macro $(\mathrm{Ca}$ and $\mathrm{P})$ and trace minerals $(\mathrm{Zn}, \mathrm{Cu}$ and $\mathrm{Mn})$ among the four season no significant difference observed. It may be concluded that $\mathrm{P}, \mathrm{Zn}$ and $\mathrm{Mn}$ need supplementation for balancing the total ration feed in different season to optimize productivity in dairy animals. This study results suggest that mineral contents of common feeds and fodders under existing feeding practices have to be evaluated regularly to identify the deficiency and development of supplementation strategies necessary to optimize productivity of animals.
\end{abstract}

\section{Introduction}

Deficiency diseases are quite common in high producing animals and are mainly due to nonavailability of balanced diet or imbalance of specific nutrients in soil and fodder. Abdelrahaman et al. (1998) reported that condition of tropical areas significantly affects the quality and quantity of forages. In India, dietary concentration of macro and micro minerals are highly variable in its availability depends on season, location and forage intake through feed apart from nonnutritional factors such as age, weight, 
pregnancy and lactation stages (Khan, 1995). Cropping pattern, soil type, rainfall and feeding system are different in different agroclimatic conditions and hence the extent and type of mineral deficiency is likely to be different (Garg et al., 2005). Under nutrition, which is mainly due to lack of sufficient energy and protein is often the cause for suboptimal livestock production. However, mineral imbalances in soils and plants have long been held responsible for lower production and reproduction even in the animals given adequate feed supply. The extent of mineral deficiency in the ration of the animals is dependent on the mineral levels in the feed and fodders and the level of feeding and physiological status of animals (Garg et al., 2008).

Mineral deficiency is an area problem (Mc Dowell et al, 1983). ). Notably, wheat straw in the northern India and paddy straw in the rice dominant regions constitute bulk of dry fodder fed to dairy animals. Nearly $44 \%$ of the animal feed produced in India is estimated to come from crop residues, such as rice and wheat straw, stovers of coarse cereals and about one third comes from cultivated green fodder (NIANP, 2005).

Information regarding seasonal variation of different feeds and fodders of minerals fed to high yielding Karan Fries cattle in herd level is lacking. The present investigation was carried out to at Karan Fries herd at NDRI, Karnal to analyse the seasonal variation in essential minerals in feeds and fodders fed to these animals.

\section{Materials and Methods}

The study was conducted at Cattle Yard of Livestock Farm located at National Dairy Research Institute, Karnal. A subtropical climate prevails in the area. There are four major seasons in the year viz. winter
(December to March), summer (April to June), rainy (July to September) and autumn (October to November).

Samples of various fodders fed to KF cattle were collected in different seasons.

Season: I Rainy - Maize, Jowar, Maize Dry, Wheat Bhusa and Concentrate

Season: II Autumn - Maize, Jowar, Maize Dry, Jowar Dry, Cowpea and Concentrate Season: III Winter - Maize, Jowar, and Jowar dry, Mustard, Turnip, Berseem, Wheat bhusa, Lucerne, Oats and concentrate Season: IV Summer - Maize, Berseem, Lucerne, Wheat bhusa, Cowpea dry, and concentrate

Four samples of each fodder (green and dry)and concentrates mentioned above were collected in each month (one sample per week) in the respective season. The individual fodder samples were weighed before to dry in a hot air oven at $100 \pm 5{ }^{\circ} \mathrm{C}$ for $8 \mathrm{hrs}$, and weighed after drying to estimate dry matter content of feed and fodder sample. From the four sample collected in a month, a representative sample was obtained after thoroughly mixing samples of a particular fodder. Then dried samples grinded and stored in air tight polythene packets for analysis on dry matter basis The fodder samples were digested by the method of Trolson (1969). Concentrations of calcium, zinc, copper and manganese were determined using Atomic Absorption Spectrophotometer (Perkin Elmer A Analyst 100) with standard solution of different concentrations of elements in order to estimate the final concentration of minerals. The concentration was expressed as parts per million (ppm). Phosphorus was estimated following the method of Fiske and Subbarow (1925).

The statistical analysis of data of differential was carried out by least squares method 
(Harvey, 1979). Product movement correlations were carried out as per Snedecor and Cochran (1994).

\section{Results and Discussion}

The profile of various macro and micro minerals in different green fodders are presented in table 1 . In summer season the overall calcium content in green fodders was higher $(0.89 \%)$ followed by winter, autumn and rainy season which was above critical level $(<0.30 \%)$; however, the level is below normal level in rainy and autumn as only maize and sorghum is available as green fodder. There was no significant $(\mathrm{P}<0.05)$ difference among the season. Phosphorus level was observed higher in winter $(0.35 \%)$ and lower in rainy and summer season just above the critical level of $(0.25 \%)$; however, there is significant difference $(\mathrm{P}<0.05)$ among the season. Zinc content of the green fodders in all seasons was around critical levels $(<30$ $\mathrm{ppm})$. There is no significant difference in other trace minerals among the season.

The present values of calcium in green fodders are higher than findings of (Sharma $e t$ al., 2002; Sharma et al., 2003a). Identical results were reported by Ramana et al. (2000) from north east transition zone of Karnataka $(0.97 \%)$ and Gowda et al.(2002) in hilly zone of Karnataka (0.6 - 6\%). Phosphorus level agreement with the findings of (Sharma et al., 2002) in part of north India, and Sharma et al. (2003a) in Kumaon hills and Sahoo at al. (2007b). The interrelationship of soilpasture- animal with respect to the availability of minerals is complex (McDowell, 1993). The young grasses which usually retain more phosphorus than the mature grass may be one of the reasons of high phosphorus in winter. Though the phosphorus level was found within the normal level however, availability of phosphorus to animals is less perhaps due to excess of dietary iron $(\mathrm{Fe})$ in fodder which might have reduced the availability of phosphorus to animals by forming ferricphosphate in plant (Suttle, 1967).

Phosphorus content of soil and plant was higher during summer and lower during winter and thus availability of phosphorus to the animals was lower in winter than that in other season (Mandal et al., 1972). However, in our study green fodder has higher phosphorus in winter than summer may be due to uniform quality and mainly berseem green fodder and poor quality of green fodder in summer which is maize and sorghum. Forages in the early growth stage contain higher amounts of minerals, which declines in the forages nearing maturity (McDowell, 1985). During summer the slight higher levels of these minerals in serum were observed due to consumption of forages rich in minerals. Baruah et al. (2000) reported that the concentrations of different macro and micro minerals in soil, forage and blood serum of prepubertal Jersey heifers were higher during summer compared to the winter. During summer these minerals were higher levels which might be due to the summer season which coincides with rainy season, there is growth of lush green pastures. This may be a region specific issue to be addressed specifically.

Sharma et al. (2003a) found lower zinc level (23 ppm) in fodder than the present findings in Karnal as he has collected samples from field level. The uptake of minerals particularly copper, zinc and iron in soil to plant is better from acidic soil as compared to alkaline soils (William, 1977). The decreased level of zinc of these fodders might be due to deficiency of zinc in the soil, alkalinity of soil and excessive use of fertilizers which interferes in the absorption of minerals by the fodder (Sharma et al., 2002) which true to Karnal soil quality due to rice wheat intensive cropping pattern. Low soil content of zinc 
may be reflected in fodders grown on deficient soils. Garg et al. (2004) recorded low zinc level in almost all the feedstuff of Kutch district of Gujarat. Sharma and Joshi (2005) observed significantly deficiency $(<30$ ppm) of zinc in fodder in northern India. It is evident from the present findings that there is existence of a significant soil-plant- animal relationship in respect of micronutrient deficiencies which may lead to infertility condition in cattle. The copper level in our finding is in agreement with findings of Yadav et al., (2002). Manganese level is also comparable to Yadav et al. (2002) in Panipat, Garg et al. (2003) in Gujarat and the levels are above the critical limits $(\mathrm{Cu}<8$ ppm and $\mathrm{Mn}<40 \mathrm{ppm}$ ) in all season.

Khan et al. (2006) reported that in Punjab seasonal effects were observed in copper, iron, zinc, manganese and selenium for forages, we have also found such trend in the different fodder samples. Forages contained marginal to deficient levels of cobalt during the winter, copper and selenium during the summer and moderately deficient levels of iron and severely deficient levels of zinc, manganese and cobalt during the summer. In forages copper, iron, zinc, manganese and selenium during winter were found to be adequate for the requirements of ruminants. Zinc levels during summer were at marginal deficient levels. Although forage microminerals were within the range required by the ruminants, they were not sufficiently high to prevent the predisposition to various diseases caused by nutrient deficiency and factors which greatly reduce forage intake, such as low protein $(<7.0)$ content and increased degree of lignifications, likewise reduce the total minerals consumed.

The profile of various macro and micro minerals in different dry roughages are presented in table 2 . In dry roughages higher level of calcium was observed in summer season $(0.47 \%)$ compare to the other seasons.
But there was no significant difference among the season. Phosphorus level was higher in summer $(0.42 \%)$ lower in rainy $(0.27 \%)$ and significant difference $(\mathrm{P}<0.05)$ in summer and rainy and autumn season. Trace minerals zinc, copper and manganese were higher level in summer and no significant difference among the season. The zinc level was below the critical level (<30 ppm) observed in all season. Majority of the roughages have been found to be deficient in zinc $(<30 \mathrm{ppm})$ in different parts of Haryana. Copper level was observed above the critical level ( $<8 \mathrm{ppm})$. Manganese level observed below the critical level $(<40 \mathrm{ppm})$ in all the season.

In dry roughages calcium level was comparable to the findings of Yadav et al. (2002) Panipat in Haryana. In Karnataka (Gowda et al. (2002) and Tripura (Ramana et al., 2001 and Datt, 2002) the calcium levels was above the critical level in all the seasons. The phosphorus level is in agreement with the findings of Kalitha et al. (2003) and values were just above the critical level $(<0.25 \%)$ observed in the present findings. Generally temperate forages contain more phosphorus than tropical ones $(0.35 \%$ vs. $0.23 \%)$ and legumes slightly more than grasses $(0.32$ vs. $0.27 \%$ ) (Minson, 1990). Copper values comparable with the findings of (Yadav et al., 1998; Gowda et al., 2002; Garg et al., 2003, and Kalitha et al., 2003). A dietary supplementation of zinc has been recommended as the animals were also reported to be deficient. Similar reports are also available from Jhajjar (Kapoor et al., 2004). The manganese level was comparable to findings of (Garg et al., 1999; Yadav et al., 2002; Mann et al., 2003; Gowda et al., 2003). In Haryana (Karnal) manganese content in various dry roughages and tree leaves was found to be deficient (Singhal and Mudgal, 1984). A dietary supplementation of manganese has been recommended to overcome the deficiency. 
Table.1 Mineral profile of green fodders in different season (Mean \pm SE)

\begin{tabular}{|l|c|c|c|c|c|}
\hline Minerals/Season & $\begin{array}{c}\text { Critical } \\
\text { level }\end{array}$ & Rainy & Autumn & Winter & Summer \\
\hline $\mathrm{Ca}(\%)$ & $<0.30$ & $0.68 \pm 0.02$ & $0.69 \pm 0.03$ & $0.78 \pm 0.08$ & $0.89 \pm 0.11$ \\
\hline $\mathrm{P}(\%)$ & $<0.25$ & $0.30 \pm 0.03^{\mathrm{a}}$ & $0.33 \pm 0.02^{\mathrm{ab}}$ & $0.35 \pm 0.02^{\mathrm{b}}$ & $0.30 \pm 0.02^{\mathrm{a}}$ \\
\hline $\mathrm{Zn}(\mathrm{ppm})$ & $<30$ & $29.84 \pm 0.50$ & $32.57 \pm 0.56$ & $34.99 \pm 0.07$ & $34.43 \pm 0.71$ \\
\hline $\mathrm{Cu}(\mathrm{ppm})$ & $<8$ & $24.82 \pm 0.17$ & $23.96 \pm 0.82$ & $24.19 \pm 0.69$ & $24.31 \pm 0.39$ \\
\hline $\mathrm{Mn}(\mathrm{ppm})$ & $<40$ & $46.07 \pm 0.65$ & $50.86 \pm 0.54$ & $57.83 \pm 0.94$ & $59.15 \pm 0.19$ \\
\hline
\end{tabular}

Means with different superscript in a row differ significantly $(\mathrm{P}<0.05)$

Table.2 Mineral profile of dry roughages in different season (Mean \pm SE)

\begin{tabular}{|l|c|c|c|c|c|}
\hline Minerals/Season & $\begin{array}{c}\text { Critical } \\
\text { level }\end{array}$ & Rainy & Autumn & Winter & Summer \\
\hline $\mathrm{Ca}(\%)$ & $<0.30$ & $0.46 \pm 0.03$ & $0.44 \pm 0.01$ & $0.48 \pm 0.04$ & $0.47 \pm 0.04$ \\
\hline $\mathrm{P}(\%)$ & $<0.25$ & $0.27 \pm 0.03^{\mathrm{a}}$ & $0.28 \pm 0.01^{\mathrm{a}}$ & $0.33 \pm 0.04^{\mathrm{ab}}$ & $0.42 \pm 0.04^{\mathrm{b}}$ \\
\hline $\mathrm{Zn}(\mathrm{ppm})$ & $<30$ & $18.5 \pm 0.78$ & $18.24 \pm 0.68$ & $17.63 \pm 0.62$ & $24.12 \pm 0.45$ \\
\hline $\mathrm{Cu}(\mathrm{ppm})$ & $<8$ & $12.91 \pm 0.03$ & $14.81 \pm 0.01$ & $15.13 \pm 2.33$ & $16.24 \pm 0.99$ \\
\hline $\mathrm{Mn}(\mathrm{ppm})$ & $<40$ & $32.6 \pm 0.05$ & $34.04 \pm 0.68$ & $32.99 \pm 0.41$ & $35.39 \pm 0.07$ \\
\hline
\end{tabular}

Means with different superscript in a row differ significantly $(\mathrm{P}<0.05)$

Table.3 Mineral profile of concentrates in different season (Mean \pm SE)

\begin{tabular}{|l|c|c|c|c|c|}
\hline Minerals/Season & $\begin{array}{c}\text { Critical } \\
\text { level }\end{array}$ & Rainy & Autumn & Winter & Summer \\
\hline $\mathrm{Ca}(\%)$ & $<0.30$ & $0.51 \pm 0.04$ & $0.44 \pm 0.03$ & $0.52 \pm 0.03$ & $0.47 \pm 0.01$ \\
\hline $\mathrm{P}(\%)$ & $<0.25$ & $0.53 \pm 0.01$ & $0.52 \pm 0.01$ & $0.47 \pm 0.04$ & $0.57 \pm 0.06$ \\
\hline $\mathrm{Zn}(\mathrm{ppm})$ & $<30$ & $39.66 \pm 0.88$ & $43.82 \pm 0.86$ & $42.28 \pm 0.88$ & $38.52 \pm 0.58$ \\
\hline $\mathrm{Cu}(\mathrm{ppm})$ & $<8$ & $31.3 \pm 0.34$ & $31.26 \pm 0.65$ & $27.31 \pm 0.34$ & $26.14 \pm 0.19$ \\
\hline $\mathrm{Mn}(\mathrm{ppm})$ & $<40$ & $58.59 \pm 0.14$ & $62.51 \pm 0.04$ & $56.31 \pm 0.78$ & $55.48 \pm 0.60$ \\
\hline
\end{tabular}

The profile of various macro and micro minerals in concentrates in different seasons are presented in table 3. Both macro $(\mathrm{Ca}$ and $\mathrm{P})$ and trace minerals ( $\mathrm{Zn}, \mathrm{Cu}$ and $\mathrm{Mn}$ ) among the four season no significant difference observed but phosphorus level was lowest in winter season than the other season. However, the levels of these minerals were above critical limit in all season. Shinde and Sankhyan (2008) reported that dry roughages were highly deficient in zinc, copper and manganese. Available concentrate feeds were also found to be deficient in zinc, copper and manganese to varied extent but the iron 
content was invariably higher than the required level $(50 \mathrm{ppm})$ in all the feeds and fodders. On the basis of animal data obtained, a deficiency of $50-70 \%$ of calcium, phosphorus and copper has been recorded in Mohindergarh and Rewari districts of Haryana. Sharma et al. (2003c) Studies carried out in buffaloes of Gurgaon district revealed deficiency of calcium and zinc in a large population of buffaloes (80 and 52\%, respectively). Calcium deficiency was also recorded in large number of buffaloes (73\%) in Faridabad district besides exhibiting manganese deficiency (63\%). Further, an alarmingly high level of zinc and manganese deficiency was observed in Bhiwani (99 and $96 \%$, respectively of buffalo population) and Rohtak districts (80 and 67\%, respectively of buffalo population) besides calcium and copper deficiency. A deficiency of calcium, phosphorus and zinc in 40, 33 and $61 \%$ of overall buffalo population, respectively was recorded in Jhajjar district. Similarly, 30-45\% of buffaloes of Hisar and Fatehabad districts have been observed to be deficient in calcium, phosphorus, copper and zinc. In Kurukshetra district also, zinc and phosphorus deficiency was recorded in $40-50 \%$ of buffaloes. Calcium, phosphorus and zinc deficiency were found in Panipat, Sonepat, Yamunanagar, Ambala and Kaithal districts.)

It may be concluded that $\mathrm{P}, \mathrm{Zn}$ and $\mathrm{Mn}$ need supplementation for balancing the total ration feed in different season to optimize productivity in all groups of animals. This study results suggest that mineral contents of common feeds and fodders under existing feeding practices have to be evaluated regularly to identify the deficiency and development of supplementation strategies necessary to optimize productivity of animals.

\section{Acknowledgement}

The authors are thankful to Director, National
Dairy Research Institute (NDRI), Karnal and Dr. Shiv Prasad, in-charge Livestock Research Center, National Dairy Research Institute, Karnal for providing research facilities.

\section{References}

Abdelrahaman, M. M., Kincad, P. L. and Elzubejr, E. A. 1998. Mineral deficiencies in grazing dairy cattle in Kordofan and Darfur regions in Lalestern Sudan. Trop. Anim. Health Prod., 30:123-135.

Baruah, A., Baruah, K. K. and Bhattacharya B. N., 2000. Certain macro and micro minerals in prepubertal Jersey heifers in relation to soil and forage. Indian $J$. Anim. Sci., 70: 93-95.

Datt, C. 2002-04. Annual report. ICAR Res. complex for NEH region, Umiam, Meghalaya.

Fiske, C. H. and Subbarow, Y. 1925. The colorimetric determination of phosphorus. J. Biol. Chem., 66: 375-400

Garg, M. R., Bhandari, B. M. and Sherasia, P. L. 2003. Macro and micro minerals status of feeds and fodders in Kota district of Rajasthan. Indian J. Anim. Nutr. 20: 252-261.

Garg, M. R., Bhandari, B. M. and Sherasia, P. L. 2005. Assessment of adequacy of macro and micro mineral content of feedstuffs for dairy animals in semiarid zone of Rajasthan. Anim. Nutr. Feed Tech., 5: 9-20.

Garg, M. R., Bhandari, B. M. and Sherasia, P. L. and Singh D. K. 1999. Mapping of certain minerals in feeds and fodders in the Mehsana district of Gujarat state. Indian J. Dairy Sci., 52: 68-77.

Garg, M. R., Bhanderi, B. M., Kumar. S. and Sherasia, P. L. 2008. Macro and micro mineral status of dairy animals in hilly zone of Kerala. Anim. Nutr. Feed Techn., 8: 13-23. 
Gowda, N. K. S., Malathi, V. and Suganthi, R. U. 2003. Screening for aflatoxin and effect of moisture, duration of storage and form of feed on fungal growth and toxin production in livestock feeds. Anim. Nutr. Feed Tech., 3: 45-51.

Gowda, N. K. S., Prasad, C. S., Ramana , J. V. and Sivaramalu, M. T. 2002. Assessment of mineral status in hilly and central dry zones of Karnataka and to supplement them. Indian. J. Anim. Sci., 72: 165-170.

Harvey. W .R. 1979. Least Squares analysis of data with unequal subclass numbers. U.S. Department of Agriculture Research Science and Education Administration.

Kalita, D. J., Sarmah, B .C. Sarmah, D. N. and Mili, D. C. 2003. Mineral status and their retention In lactating cows in relation to soil, fodder and feed in Kamrup district of Assam. Indian J. Anim. Nutr., 20: 421-423.

Kapoor, V., Yadav, K. K, Yadav, P. S. and Akabar, M. A. 2004. Mineral status of feeds and fodders and buffaloes in Jhajjar district of Haryana. In: Proc. of XI Animal nutrition conference. JNKVV, Jabalpur.

Khan, M. A. 1995. Effect of seasons and physical-physiological state on blood levels of minerals in crossbred cattle. M.Sc. (Ag) thesis submitted to G.B.P.U.A \& T., Pantnagar, India.

Khan, Z. I., Hussain, A., Ashraf, M. and McDowell, L. R. 2006. Mineral Status of Soils and Forages in Southwestern Punjab-Pakistan: Micro-minerals. Asian-Aust. J. Anim. Sci., 19: 11391147.

Mandal, S. C, Sinha K. K. and Sinha, M. P. 1972. Soils of India. $1^{\text {st }}$ Ed., pp. 63-66. The Fertilizer Association of India, Delhi, India.pp.109-123.

Mann, N. S., Mandal, A. B., Yadav, P. S., Lall, D. and Gupta, P. C. 2003. Mineral status of feeds and fodders in Rohtak district of Haryana. Anim. Nutri. Feed Techn., 3: 1-7.

McDowell, L. R. 1985. Nutrition of grazing ruminants in warm climates. Academic Press. Orlando, Florida.pp.157-164.

McDowell, L. R., Conrad, J. H. and Ellis, G. L. 1983. Research in mineral deficiencies for grazing ruminants. Annual report and mineral research project. University of Florida Gainesville, USA. pp. 1-86.

McDowell, L. R., Conrad, J. H., and Glen Hembry, F. 1993. Minerals for grazing ruminants in tropical regions. Animal science department, Centre for tropical agriculture, University of Florida. The U.S. Agency for international development and Caribbean basin advisory group (CBAG).pp.241-245.

Minson, D. J. 1990. Forages in ruminant nutrition. Academic press, San Diago, USA.pp. 34-45.

NIANP. 2005. Feed Base. Animal and Feed resources Database, National Institute for Animal nutrition and physiology, Bangalore.

Ramana, J. V., Prasad, C. S. and Gowda, N. S. K. 2000. Mineral profile of soil, feeds, fodders and blood plasma in southern transition zone of Karnataka. Indian J. Anim. Nutr., 17: 179-183.

Ramana, J. V., Prasad, C. S., Gowda, N. K. S. and Ramchandra, K. S., 2001. Levels of micronutrients in soil, feed, fodder and animals of North-East transition and dry zones of Karnataka. Indian J. Anim. Nutr., 18: 235-242.

Sahoo, N., Rout, P. R., Samal, P. C. and Sardar, K. K. 2007a. Macromineral status in soil, pasture and serum of grazing cattle in Orissa. Indian Vet. J., 85: 274-276.

Sharma, M. C, Joshi, C. and Sarkar, T. K. 2003a. Status of macro minerals in soil, fodder and serum of animals in kumoun 
hills. Indian J. Anim. Sci., 73: 308-311.

Sharma, M. C. and Joshi, C. 2005. Therapeutic efficacy of zinc sulphate used in clustered model treatment in alleviating zinc deficiency in cattle and its effect on hormones, vitamins and production parameters. Vet. Res. Commun., 28: 7-20.

Sharma, M. C., Joshi, C. and Sarkar, T. K. 2002. Therapeutic efficacy of mineral supplement in macro mineral deficient buffaloes and effect on haematobiochemical profile and production. Asian- Aust. J. Anim. Sci., 15: 1278-1287.

Sharma, M. C., Raju, S., Joshi, C., Kaur, H. and Varshney, V. P. 2003c. Studies on serum micro mineral, hormone and vitamin profile and its effect on production and therapeutic management of buffaloes in Haryana state of India. Asian-Aust. J. Anim. Sci., 16: 519-528.

Shinde, A. K, and Sankhyan, S. K. 2008. Mineral contents of locally available feeds and fodders in flood prone eastern plains of Rajasthan and dietary status in ruminants. Anim. Nutr. Feed Tech., 8: $35-44$.

Singhal, K. K. and Mudgal, V. D. 1984.
Macro and micro elements of feed, fodder and Agro - industrial by products. Indian. J. Anim. Sci., 54: 685691.

Snedecor, G. W. and Cochran, W. G. 1994. Statistical Methods, $8^{\text {th }}$ Ed., Iowa State University Press. AMES, Iowa- 50100

Suttle, N. F. 1967. Some consequences of mineral imbalance. Nutrition conference for feed manufacturers. University of Nottingham, Longman group Ltd., U.K.pp.120-130.

Trolson, J. E. 1969. Outline for in vitro digestion of forage samples. Research Station, Shift Current, Saskatchewan, Canada.

Williams, C. H. 1977. Trace metals and super phosphates: Toxicity problems. J. Aust. Insti Agri. Sci., 43: 99-109.

Yadav, P. S., Mandal, A. B. and Dahiya, D. V. 2002. Feeding pattern and mineral status of buffaloes in Panipat district of Haryana state. Anim. Nutr. Feed Tech., 2: $127-138$

Yadav, P. S., Mandal, A. B., Kapoor, V; Sunaria, K. R and Mann, N. S. 1998. Mineral status of cows and buffaloes in Rewari district of Haryana. Indian $J$. Anim. Sci., 68: 1059-1061.

\section{How to cite this article:}

Usha, S. and Mohanty, T.K. 2020. Assessment of Adequacy of Macro and Micro Mineral Content of Feedstuffs for Dairy Animals in Karnal District of Haryana, India. Int.J.Curr.Microbiol.App.Sci. 9(07): 3440-3447. doi: https://doi.org/10.20546/ijcmas.2020.907.402 